\title{
Impact of elevated precipitation, nitrogen deposition and warming on soil respiration in a temperate desert
}

\author{
Ping Yue ${ }^{1,2,3}$, Xiaoqing Cui ${ }^{2}$, Yanming Gong ${ }^{1}$, Kaihui $\mathbf{L i}^{1,5}$, Keith Goulding ${ }^{4}$, and Xuejun Liu ${ }^{2}$ \\ ${ }^{1}$ Key Laboratory of Biogeography and Bioresource in Arid Land, Xinjiang Institute of Ecology and Geography, \\ Chinese Academy of Sciences, Urumqi 830011, China \\ ${ }^{2}$ Key Laboratory of Plant-Soil Interactions of MOE, College of Resources and Environmental Sciences, \\ China Agricultural University, Beijing 100193, China \\ ${ }^{3}$ University of the Chinese Academy of Sciences, Beijing 100039, China \\ ${ }^{4}$ The Sustainable Soils and Grassland Systems Department, Rothamsted Research, Harpenden AL5 2JQ, UK \\ ${ }^{5}$ CAS Research Center for Ecology and Environment of Central Asia, Urumqi 830011, China
}

Correspondence: Xuejun Liu (ecology2100@sina.cn, liu310@cau.edu.cn)

Received: 31 October 2017 - Discussion started: 9 November 2017

Revised: 20 February 2018 - Accepted: 27 February 2018 - Published: 6 April 2018

\begin{abstract}
Soil respiration $\left(R_{\mathrm{S}}\right)$ is the most important source of carbon dioxide emissions from soil to atmosphere. However, it is unclear what the interactive response of $R_{\mathrm{S}}$ would be to environmental changes such as elevated precipitation, nitrogen $(\mathrm{N})$ deposition and warming, especially in unique temperate desert ecosystems. To investigate this an in situ field experiment was conducted in the Gurbantunggut Desert, northwest China, from September 2014 to October 2016. The results showed that precipitation and $\mathrm{N}$ deposition significantly increased $R_{\mathrm{S}}$, but warming decreased $R_{\mathrm{S}}$, except in extreme precipitation events, which was mainly through its impact on the variation of soil moisture at $5 \mathrm{~cm}$ depth. In addition, the interactive response of $R_{\mathrm{S}}$ to combinations of the factors was much less than that of any single-factor, and the main response was a positive effect, except for the response from the interaction of increased precipitation and high $\mathrm{N}$ deposition $\left(60 \mathrm{~kg} \mathrm{Nha}^{-1} \mathrm{yr}^{-1}\right)$. Although $R_{\mathrm{S}}$ was found to show a unimodal change pattern with the variation of soil moisture, soil temperature and soil $\mathrm{NH}_{4}^{+}-\mathrm{N}$ content, and it was significantly positively correlated to soil dissolved organic carbon (DOC) and $\mathrm{pH}$, a structural equation model found that soil temperature was the most important controlling factor. Those results indicated that $R_{\mathrm{S}}$ was mainly interactively controlled by the soil multi-environmental factors and soil nutrients, and was very sensitive to elevated precipitation, $\mathrm{N}$ deposition and warming. However, the interactions of multiple factors largely reduced between-year variation of
\end{abstract}

$R_{\mathrm{S}}$ more than any single-factor, suggesting that the carbon cycle in temperate deserts could be profoundly influenced by positive carbon-climate feedback.

\section{Introduction}

Global climate warming, changes in precipitation patterns and increased atmospheric nitrogen $(\mathrm{N})$ deposition have all occurred since the Industrial Revolution, especially in temperate regions (IPCC, 2013), which will be expected to significantly change soil respiration $\left(R_{\mathrm{S}}\right)$, the most important source of carbon dioxide $\left(\mathrm{CO}_{2}\right)$ from soil to atmosphere $(\mathrm{Wu}$ et al., 2011): the annual $\mathrm{CO}_{2}$ flux from $R_{\mathrm{S}}$ was 10 -fold that of fossil fuel emissions (Eswaran et al., 1993; Batjes, 1996; Gougoulias et al., 2014). Therefore, even a small change in $R_{\mathrm{S}}$ will profoundly affect greenhouse gas balance and climate (Heimann and Reichstein, 2008). Although a number of experiments of the effects of warming, precipitation and $\mathrm{N}$ deposition on $R_{\mathrm{S}}$ have been conducted in alpine grasslands, tundra regions, peatlands and temperate forests (Lafleur and Humphreys, 2008; Strong et al., 2017; Yang et al., 2017; Zhao et al., 2017), studies in temperate desert ecosystems are scarce, especially those on the impact of these changes' interactions on $R_{\mathrm{S}}$. A field study of multi-factor interactive effects on $R_{\mathrm{S}}$ was therefore conducted in a temperate desert ecosystem to help in understanding the response of $R_{\mathrm{S}}$ to climate 
change and $\mathrm{N}$ deposition in future and highlight the main driving factors.

$R_{\mathrm{S}}$ includes autotrophic respiration $\left(R_{\mathrm{A}}\right)$, which is mainly from plant roots and mycorrhizal activities, and heterotrophic respiration $\left(R_{\mathrm{H}}\right)$, which is mainly from the activities of microorganisms (Hanson et al., 2000). Soil moisture is a critical limiting factor for plant roots and microbial activities in desert ecosystems (Huang et al., 2015a): $R_{\mathrm{S}}$ significantly increased, by $47-70 \%$, in a degraded steppe in Inner Mongolia, China, due to increasing precipitation (Chen et al., 2013), with the effect especially strong in summer (Zhang et al., 2017). In addition, in arid ecosystems, increasing precipitation significantly stimulated plant growth, enhanced soil microbial activity and abundance (Huang et al., 2015a), and it changed soil nutrient and substrate concentration, such as dissolved organic carbon (DOC), inorganic nitrogen content, moisture and temperature (Huang et al., 2015b).

Warming significantly increased soil temperature, another important controlling factor for plant growth and microbial activity (Sheik et al., 2011; Huang et al., 2015a). $R_{\mathrm{S}}$ rates were significantly increased in a forest soil and Tibetan Plateau grassland by warming (Chen et al., 2017a), reducing $R_{\mathrm{S}}$ with decreasing soil moisture in the growing season, but increasing $R_{\mathrm{S}}$ in the non-growing season (Fang et al., 2017; Li et al., 2017); no significant impact was observed from warming (T. Liu et al., 2016). Therefore, how $R_{\mathrm{S}}$ is affected by warming induced variations in the soil environment is still unclear. In addition, low and short-term $\mathrm{N}$ deposition enhanced $R_{\mathrm{s}}$, while higher and long-term $\mathrm{N}$ deposition inhibited $R_{\mathrm{S}}$ due to changes in plant growth and microbial activity (Zhu et al., 2017), but no impacts have also been reported (Luo et al., 2017; Zhang et al., 2017). A meta-analysis showed that the effects of $\mathrm{N}$ enrichment on soil $\mathrm{CO}_{2}$ fluxes depended on temperature and soil properties (Zhong et al., 2016); desert soils may be even more sensitive to its variation.

A nation-wide analysis showed that warming, elevated $\mathrm{N}$ deposition and precipitation significantly increased $R_{\mathrm{S}}$ in China (Feng et al., 2017). Some studies have shown that the warming effect on $R_{\mathrm{S}}$ mainly depended on the variation of soil moisture in a dry forest soil (Li et al., 2017). Luo et al. (2008), using a modeling analysis, found that interactive effects became increasingly weaker with increasing intensity of the factors, but a recent meta-analysis showed that interactive effects were much greater than an individual factor (L. Y. Zhou et al., 2016). Thus how multi-factor interactions impact $R_{\mathrm{S}}$ is still unclear. Therefore, an in situ experiment was carried out in the Gurbantunggut Desert to (1) investigate the single-factor and interactive responses of $R_{\mathrm{s}}$ to warming, precipitation and $\mathrm{N}$ deposition and (2) identify the main controlling factors on $R_{\mathrm{S}}$.

\section{Materials and methods}

\subsection{Study site}

A field experiment was carried out at the southern edge of the Gurbantunggut Desert ( $44^{\circ} 26^{\prime} \mathrm{N}, 87^{\circ} 54^{\prime} \mathrm{E}$; $436.8 \mathrm{~m}$ a.s.1.), northwest China, from September 2014 to October 2016. This is the largest fixed/semi-fixed temperate desert in China. The mean annual temperature and precipitation are $7.1^{\circ} \mathrm{C}$ and $215.6 \mathrm{~mm}$, respectively (Cui et al., 2017), and annual potential evaporation exceeds $2000 \mathrm{~mm}$. From late November to mid-March, $20-35 \mathrm{~cm}$ of snow covers the whole desert (equivalent to $38-64 \mathrm{~mm}$ rainfall; Huang et al., 2015c). The growing season is from April to October. This desert soil is of extremely low fertility and is highly alkaline (Cui et al., 2017). Soil organic carbon, total $\mathrm{N}$ content, soil $\mathrm{NO}_{3}^{-}-\mathrm{N}, \mathrm{NH}_{4}^{+}-\mathrm{N}$ contents and $\mathrm{C}: \mathrm{N}$ ratio are $2.21 \pm 0.71 \mathrm{~g} \mathrm{~kg}^{-1}, 0.08 \pm 0.003 \mathrm{~g} \mathrm{~kg}^{-1}$, $4.49 \pm 0.71 \mathrm{mg} \mathrm{kg}^{-1}, 1.38 \pm 0.74 \mathrm{mg} \mathrm{kg}^{-1}$ and $21.39 \pm 1.84$, respectively (Table 1; Cui et al., 2017). Plant species are dominated by Haloxylon ammodendron and Haloxylon persicum, and vegetation is extremely sparse, with only $30 \%$ coverage, with some spring ephemeral plants (May-June), annuals and perennial herbaceous plants (July-August; R. Liu et al., 2016). Spring ephemerals account for $>60 \%$ of the community cover and $85 \%$ of the biomass. Summer ephemerals, annuals and perennials usually account for only a small proportion of the community biomass before June, but dominate the community after the die-back of the spring annuals (Huang et al., 2015c).

\subsection{Experimental treatments}

A striking $\mathrm{N}$ deposition rate $\left(35.2 \mathrm{~kg} \mathrm{Nha}^{-1} \mathrm{yr}^{-1}\right)$ exists in the Gurbantunggut Desert due to the rapid development of agriculture and industry, with the main form being ammonium nitrate $\left(\mathrm{NH}_{4} \mathrm{NO}_{3}\right)$; deposition is split between wet $\left(19.6 \mathrm{~kg} \mathrm{Nha}^{-1} \mathrm{yr}^{-1}\right)$ and dry $\left(15.6 \mathrm{~kg} \mathrm{Nha}^{-1} \mathrm{yr}^{-1}\right.$; Song et al., 2015). In addition, according to the forecast of Galloway et al. (2008), atmospheric $\mathrm{N}$ deposition will double from the early 1990s to 2050; Liu et al. (2010) predict that precipitation in this region will increased by $30 \%$ in next 30 years. In September 2014 to August 2016, an in situ complete block interactive experiment was therefore conducted to study the impact of $\mathrm{N}$ deposition and increased precipitation on $R_{\mathrm{s}}$. The three levels of $\mathrm{N}$ deposition $\left(0 \mathrm{~kg} \mathrm{Nha}^{-1} \mathrm{yr}^{-1}\right.$, control, N0; $30 \mathrm{~kg} \mathrm{Nha}^{-1} \mathrm{yr}^{-1}$, low, N1; $60 \mathrm{~kg} \mathrm{Nha}^{-1} \mathrm{yr}^{-1}$, high, N2) and two levels of precipitation ("natural" precipitation, W0, and an increase of $30 \%$ - an extra $60 \mathrm{~mm}$ precipitation annually, W1) were applied (Cui et al., 2017). Therefore there were six treatments (W0N0, W0N1, W0N2, W1N0, W1N1 and W1N2) with four replicates of each treatment. Each replicate plot was $10 \mathrm{~m} \times 10 \mathrm{~m}$ with a $5 \mathrm{~m}$ wide buffer zone. The additional precipitation and $\mathrm{N}$ deposition $\left(\mathrm{NH}_{4} \mathrm{NO}_{3}\right)$ were added 12 times in April, 
Table 1. The annual, growing season (GS), non-growing season (NGS) and between-year fluxes and variation of soil respiration $\left(R_{\mathrm{S}}\right)$ over September 2014 to September 2016 (mean \pm SE), including the contribution of GS and NGS, and the treatment effect. The positive values stand for increased $R_{\mathrm{S}}$, and the negative value stand for reduced $R_{\mathrm{S}}$. Dates are shown in YYYY.M format.

\begin{tabular}{|c|c|c|c|c|c|c|c|c|c|c|}
\hline & \multirow{2}{*}{$\begin{array}{c}\text { Prec. } \\
\text { mm }\end{array}$} & \multirow{2}{*}{$\begin{array}{l}\text { temp. } \\
{ }^{\circ} \mathrm{C}\end{array}$} & \multicolumn{8}{|c|}{$R_{\mathrm{S}}$ rate $\left(\mathrm{kg} \mathrm{Cha}^{-1}\right)$} \\
\hline & & & WONO & W0N1 & W0N2 & W1N0 & W1N1 & W1N2 & W1N1T1 & $\mathrm{T} 1$ \\
\hline Annul & 175.75 & 4.63 & 1090.11 & 1338.26 & 1299.41 & 1450.78 & 1304.77 & 1043.77 & 1196.84 & 981.19 \\
\hline Annual & \pm 7.75 & \pm 0.36 & \pm 450.78 & \pm 599.12 & \pm 537 & \pm 543.70 & \pm 383.29 & \pm 233.23 & \pm 334.31 & \pm 371.34 \\
\hline $\mathrm{CV}(\%)$ & 4.41 & 7.78 & 41.35 & 44.77 & 41.33 & 37.48 & 29.37 & 22.34 & 27.93 & 37.85 \\
\hline Treatment effect (\%) & - & - & - & 22.76 & 19.20 & 33.09 & 19.69 & -4.25 & 9.79 & -9.99 \\
\hline \multicolumn{11}{|l|}{ Growing season } \\
\hline 2014.9-2015.8 & 120.5 & 14.67 & 508.30 & 561.95 & 570.38 & 650.66 & 669.93 & 562.04 & 561.10 & 425.35 \\
\hline 2015.9-2016.8 & 114.5 & 21.18 & 1220.27 & 1546.62 & 1506.88 & 1641.62 & 1274.93 & 1052.22 & 1183.86 & 1089.51 \\
\hline $\mathrm{CV}(\%)$ & 3.61 & 25.68 & 46.18 & 52.03 & 50.96 & 48.30 & 32.79 & 33.21 & 50.47 & 62.00 \\
\hline \multicolumn{11}{|l|}{ Non-growing season } \\
\hline 2014.9-2015.8 & 47.5 & -6.13 & 131.03 & 177.09 & 192.03 & 256.43 & 251.55 & 248.50 & 301.43 & 184.49 \\
\hline 2015.9-2016.8 & 69 & -11.2 & 320.62 & 390.84 & 329.54 & 352.85 & 413.12 & 224.79 & 347.29 & 262.02 \\
\hline $\mathrm{CV}(\%)$ & 26.10 & 41.37 & 59.37 & 53.23 & 37.29 & 22.38 & 34.38 & 7.09 & 10.00 & 24.82 \\
\hline NGS contribution & - & - & 20.65 & 22.07 & 21.57 & 22.98 & 25.89 & 24.13 & 27.10 & 22.80 \\
\hline
\end{tabular}

July and September, equivalent to $5 \mathrm{~mm}$ precipitation and 2.5 or $5 \mathrm{~kg} \mathrm{Nha}^{-1}$ per application over a week. The $\mathrm{NH}_{4} \mathrm{NO}_{3}$ was diluted in $50 \mathrm{~L}$ water (equal to $0.5 \mathrm{~mm}$ precipitation), and evenly applied following the simulated precipitation. The same amount of water was applied to the control plots (WONO).

Rapid warming $\left(0.6^{\circ} \mathrm{C}\right.$ per decade), increasing precipitation (3-5 $\mathrm{mm} \mathrm{yr}^{-1}$ since 1979) and high $\mathrm{N}$ deposition (3 $\mathrm{kg} \mathrm{Nha}^{-1}$ since 1980) are affecting the Gurbantunggut Desert (Liu et al., 2013; Li et al., 2015), which are excepted to affect rate of $R_{\mathrm{S}}$. Therefore, another interactive experiment was established at the same time, simulating the three most likely climate scenarios in the future: (1) warming only (W0N0T1), (2) increased precipitation and $\mathrm{N}$ deposition without warming (W1N1T0), (3) the interaction of increasing precipitation, $\mathrm{N}$ deposition and warming (W1N1T1); all compared with the current climate (W0NOT0). Therefore, there were four treatments (W0N0T1, W1N1T0, W1N1T1, W0NOT0) with four replicates (plots) of each treatment. Open-top chambers (OTCs) were used to simulate warming. The OTCs were designed with $5 \mathrm{~mm}$ transparent tempered glass and stainless steel angle iron to the ITEX standard (Marion et al., 1997). They were $2 \mathrm{~m}$ high and $4 \mathrm{~m}$ in diameter, with each OTC area being $12 \mathrm{~m}^{2}$. However, the design was improved such that the top and bottom OTC areas were the same so that precipitation and snowfall were the same as that in the surrounding environment; this also avoids overheating inside the OTCs. The timings of water and $\mathrm{N}$ applications were the same as in the complete block interactive experiment.

\subsection{Measurements}

$R_{\mathrm{S}}$ in all plots were measured twice or thrice a week (continuous measurements over 3 days were made following simulated precipitation and $\mathrm{N}$ deposition) using gas chromatography and static chambers $(50 \mathrm{~cm} \times 50 \mathrm{~cm} \times 10 \mathrm{~cm})$ at locations where only spring ephemeral plants grow, without any annuals and perennials, in order to minimize the betweentreatment spatial heterogeneity due to sparse annuals and perennials (Liu et al., 2012). Gas samples were collected between 10:00 and 12:00 (GMT + 8) throughout the experimental period; measurements from this period were close to the diurnal averages (Figs. 3b, d and S1 in the Supplement). Gas samples were collected from the headspace of each chamber $0,10,20$ and $30 \mathrm{~min}$ after closing the chamber. The gas samples were analyzed within 3 days using a gas chromatograph (GC; Agilent 7890A, Agilent Technologies, Santa Clara, CA, USA) equipped with a flame ionization detector for quantitative $R_{\mathrm{S}}$ (Liu et al., 2012). $R_{\mathrm{S}}$ rates were calculated from four concentrations of the gas samples based on a first-order differential linear or nonlinear equation and were temperature and pressure corrected (Liu et al., 2012; Zhang et al., 2014). Soil samples were taken monthly from around the static chambers to a depth of $10 \mathrm{~cm}$ using an auger $(3.5 \mathrm{~cm}$ in diameter). Fine roots and small stones were separated out using a $2 \mathrm{~mm}$ sieve. Dissolved organic carbon (DOC) was extracted with deionized water (soil: water ratio $=1: 10$ ) by a centrifuge at $10000 \mathrm{rpm}$ for $5 \mathrm{~min}$ and analyzed using a TOC analyzer (multi N/C 3100, Jena, Germany; Jones and Willett, 2006). The chloroform fumigation extraction of Brookes (1985) was used to measure microbial biomass carbon (MBC) and microbial biomass nitrogen (MBN). Soil organic carbon (SOC) was measured using the potassium dichromate method (Jiang et al., 2014), 

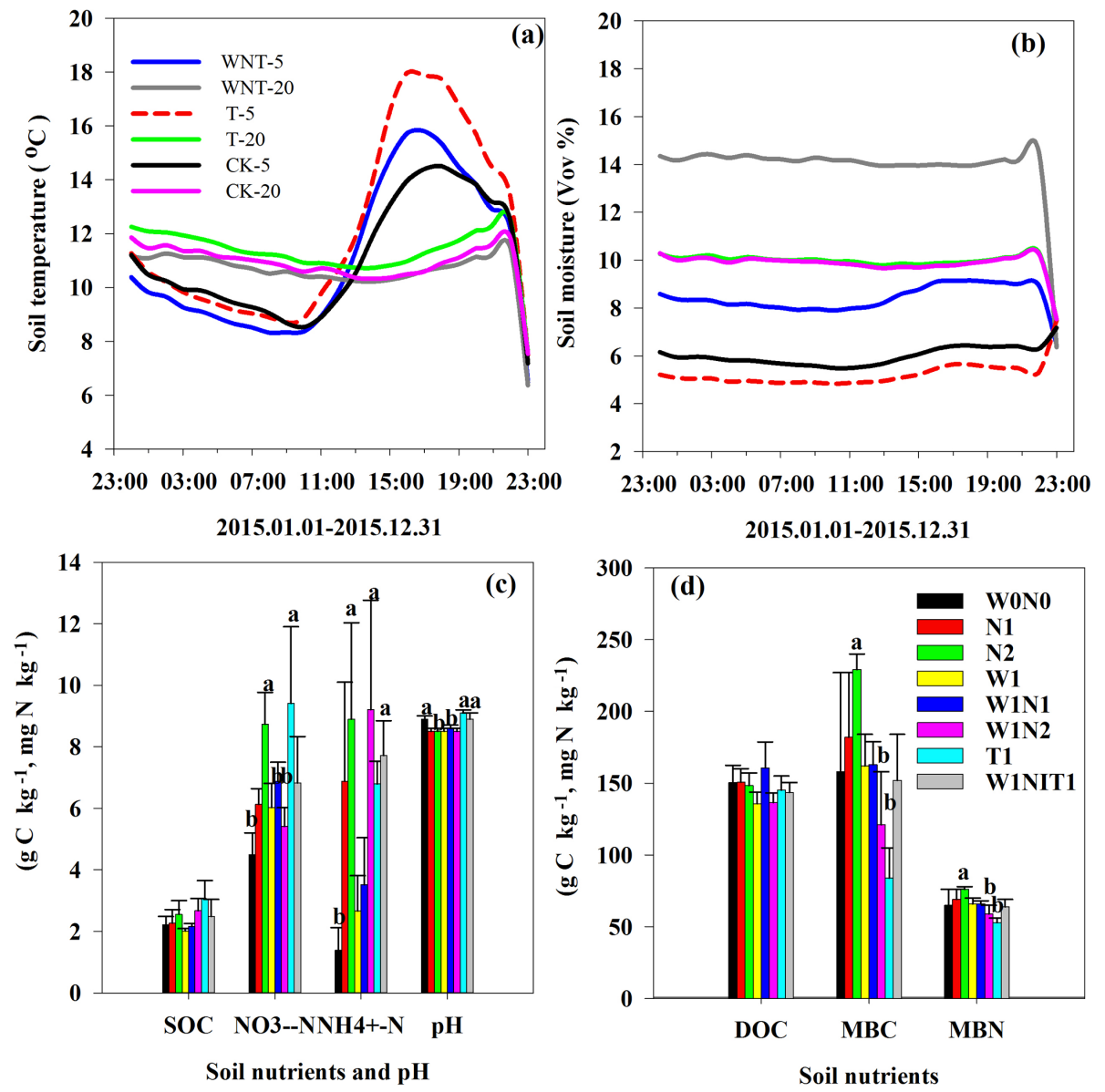

Figure 1. Comparative effects of warming from open-top chambers (OTCs), increased precipitation and $\mathrm{N}$ deposition on soil temperature (a), soil moisture (b) at 5 and $20 \mathrm{~cm}$ depth; soil organic carbon (SOC), $\mathrm{NH}_{4}^{+}-\mathrm{N}$ content, $\mathrm{NO}_{3}^{-}-\mathrm{N}$ content and $\mathrm{pH}$ (c), dissolved organic carbon (DOC), microbial biomass carbon (MBC) and microbial biomass nitrogen (MBN, d). The data are mean $\pm \mathrm{SE}, n=4$ in (c) and (d); different letters indicate significant effect at $P<0.05$.

and soil $\mathrm{NO}_{3}^{-}-\mathrm{N}$ and $\mathrm{NH}_{4}^{+}-\mathrm{N}$ was analyzed as per Yue et al. (2016). Soil $\mathrm{pH}$ was measured with a 1:5 soil: deionized water suspension using a $\mathrm{pH}$ meter (Seven Easy, MettlerToledo, Switzerland). Caipos Soil and Environment Monitoring Systems (Caipos $\mathrm{GmbH}$, Austria) were used to monitor soil moisture/temperature at 5 and $20 \mathrm{~cm}$ depth every hour.

\subsection{Effects of each treatment on $\boldsymbol{R}_{\mathrm{S}}$}

Each treatment effect was analyzed using the following formula to better evaluating the effect of precipitation, warming and $\mathrm{N}$ deposition on $R_{\mathrm{S}}$ (Yue et al., 2016).

Treatment effect $=\left(T R_{\mathrm{S}}-C R_{\mathrm{S}}\right) / C R_{\mathrm{S}} \times 100 \%$,

where the treatment effect is W0N1, W0N2, W1N0, W1N1, W1N2, W1N1T1 or W0N0T1 effect on $R_{\mathrm{S}}$ (a positive value shows that the treatment has increased $R_{\mathrm{S}}$ and a negative value shows decrease of $R_{\mathrm{S}}$ ), corresponding $R_{\mathrm{T}, \mathrm{s}}$ represents $R_{\mathrm{S}}$ from the W0N1, W0N2, W1N0, W1N1, W1N2, W1N1T1 or W0N0T1 plots $\left(\mathrm{mg} \mathrm{C} \mathrm{m}^{-2} \mathrm{~h}^{-1}\right)$ and $R_{\mathrm{C}, \mathrm{s}}$ indicates the $R_{\mathrm{S}}$ from the control plots (WONO, $\mathrm{mg} \mathrm{C} \mathrm{m}^{-2} \mathrm{~h}^{-1}$ ).

\subsection{Statistical analyses}

Treatment effect on $\mathrm{SOC}, \mathrm{NO}_{3}^{-}-\mathrm{N}, \mathrm{NH}_{4}^{+}-\mathrm{N}$ content, $\mathrm{pH}$, DOC, MBC and MBN were examined in each treatment by least significant difference (LSD; $p<0.05$ ). The single-factor and interaction effects of precipitation, warming and $\mathrm{N}$ deposition on $R_{\mathrm{S}}$ were detected using multi-way analysis of variance (ANOVA), and the cumulative effect of precipitation, warming and $\mathrm{N}$ deposition on $R_{\mathrm{S}}$ were tested by repeated measures ANOVA. In addition, the relationships of $R_{\mathrm{S}}$ and DOC, MBC, MBN, soil temperature, soil moisture, $\mathrm{NH}_{4}^{+}-\mathrm{N}$ content, soil $\mathrm{NO}_{3}^{-}-\mathrm{N}$ and $\mathrm{pH}$ were described using a linear or nonlinear regression model. The factors of key controls on $R_{\mathrm{S}}$ were analyzed with structural equation models (SEMs). SPSS software (version 20.0) was used to conduct all statistical analyses, and statistically significant differences were set at $P<0.05$. All figures were created using the Sigmaplot 


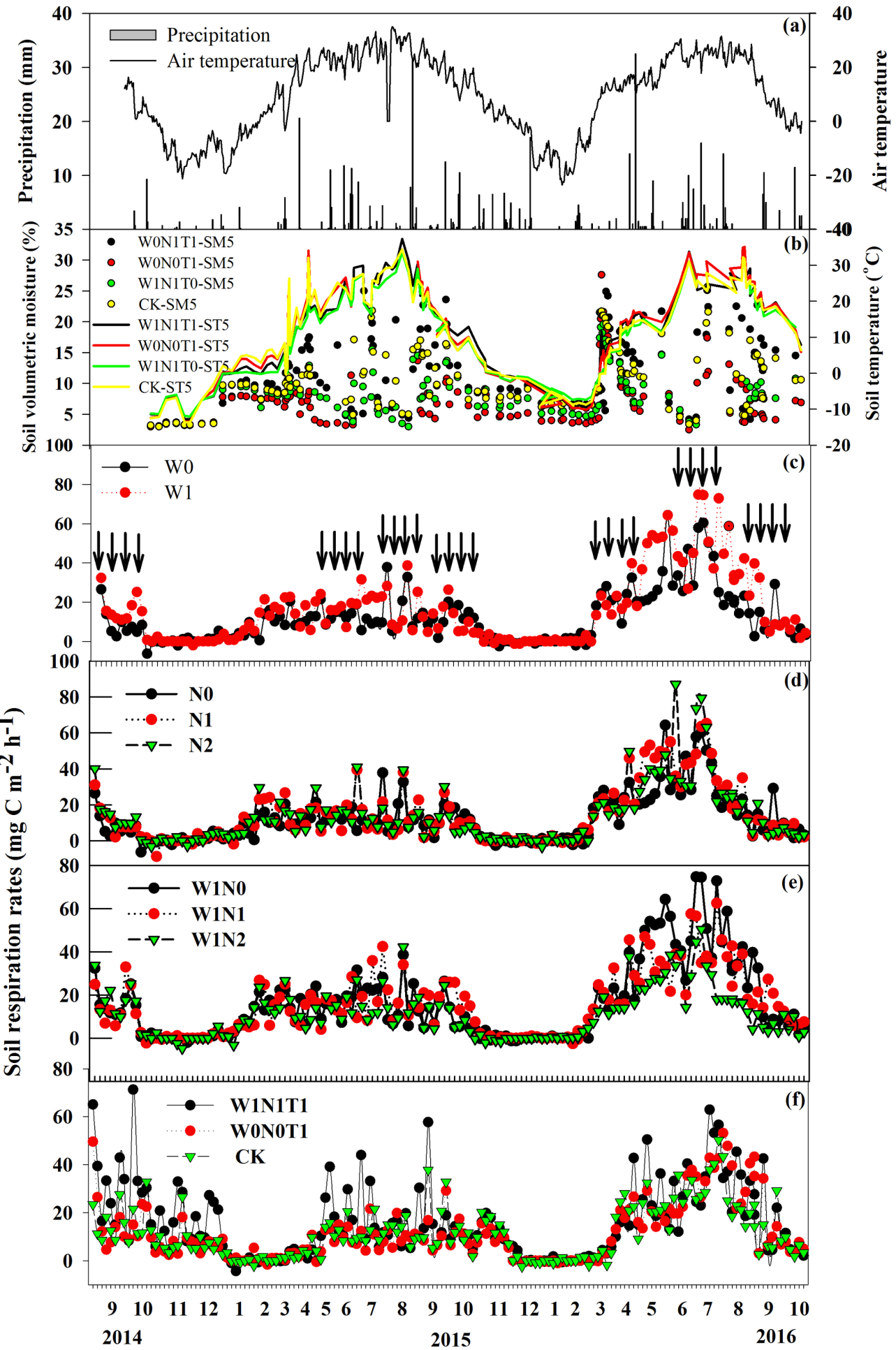

Figure 2. Variation in rainfall (mm, a), and air temperature $\left({ }^{\circ} \mathrm{C}\right.$, a) from September 2014 to October 2016 at the Gurbantunggut Desert. Also shown are soil moisture and temperature responses to increasing precipitation and warming $(\mathbf{b})$, and the response of $R_{\mathrm{S}}($ mean, $n=4)$ to precipitation (c), $\mathrm{N}$ deposition (d, e) and warming (f). W0 and W1 indicate under ambient precipitation (without water addition) and $60 \mathrm{~mm} \mathrm{yr}^{-1}$ precipitation addition; N0, N1 and $\mathrm{N} 2$ indicate 0,30 and $60 \mathrm{~kg} \mathrm{Nha}^{-1} \mathrm{yr}^{-1}$ nitrogen addition; W1N0, W1N1 and W1N2 indicate 0,30 and $60 \mathrm{~kg} \mathrm{Nha}^{-1} \mathrm{yr}^{-1}$ nitrogen addition under $60 \mathrm{~mm} \mathrm{yr}^{-1}$ precipitation addition; W1N1T1, W0N0T1 and W0N0T0 indicate the interaction between increasing precipitation $\left(60 \mathrm{~mm} \mathrm{yr}^{-1}\right), \mathrm{N}$ deposition $\left(30 \mathrm{~kg} \mathrm{~N} \mathrm{ha}^{-1} \mathrm{yr}^{-1}\right)$ and warming by OTCs, warming alone (without increasing precipitation and $\mathrm{N}$ deposition) and control plots, respectively. Black arrows indicate simulated precipitation (5 mm) and $\mathrm{N}$ deposition $\left(0.25\right.$ or $\left.0.5 \mathrm{~g} \mathrm{~N} \mathrm{~m}^{-2}\right)$. Each point represents the mean of four replications (chambers). Standard deviations for $R_{\mathrm{S}}$ are not shown for figure clarity. 
software package (version 10.0), but SEM analyses were carried out using AMOS 22.0 (Amos Development Corporation, Chicago, IL, USA).

\section{Results}

\subsection{Treatment effects on soil environmental and properties}

Soil temperatures at $5 \mathrm{~cm}$ depth mostly increased between 11:00 and 22:00 every day due to warming; the average annual soil temperatures at 5 and $20 \mathrm{~cm}$ depth increased significantly, by 4.41 and $3.67^{\circ} \mathrm{C}$, respectively (Fig. 1a). Soil moisture at $5 \mathrm{~cm}$ depth was decreased by warming by only $0.61 v / v \%$ (Fig. 1b), and a very small decrease of $0.01 v / v \%$ in soil moisture at $20 \mathrm{~cm}$ depth was observed (Fig. 1b). Soil moisture at 5 and $20 \mathrm{~cm}$ depth were largely increased by the increased precipitation (Fig. 1b). $\mathrm{N}$ deposition and warming significant increased soil $\mathrm{NH}_{4}^{+}-\mathrm{N}$ and $\mathrm{NO}_{3}^{-}-\mathrm{N}$ contents (Fig. 1c), but no significant change was found from increased precipitation. Soil MBC and MBN were greatly increased by $\mathrm{N}$ deposition, but significant negative effects on soil MBC and MBN were observed by warming and the interaction of precipitation and $\mathrm{N}$ deposition (Fig. 1d). No significant change in SOC and DOC was observed in any treatment (Fig. 1c and d).

\subsection{Precipitation, warming and $\mathrm{N}$ deposition effects on $R_{\mathrm{S}}$}

In our study, a weak $R_{\mathrm{S}}$ emission rate $(-2.46$ to $50.26 \mathrm{mg} \mathrm{C} \mathrm{m}^{-2} \mathrm{~h}^{-1}$ ) was observed at control plots with an average emission rate of $12.18 \mathrm{mg} \mathrm{C} \mathrm{m}^{-2} \mathrm{~h}^{-1}$ from September 2014 to October 2016 (Fig. 2c). Annual cumulative rate of $R_{\mathrm{S}}$ was $1090.11 \pm 450.78 \mathrm{~kg} \mathrm{Cha}^{-1}$, with the nongrowing season accounting for $20.7 \%$ of the annual emission (Table 1$). R_{\mathrm{S}}$ was significantly enhanced by increasing $5 \mathrm{~mm}$ precipitation and $\mathrm{N}$ deposition from 12.18 to 16.23 and to $14.97 \mathrm{mg} \mathrm{C} \mathrm{m}^{-2} \mathrm{~h}^{-1}$ (average), respectively $(P<0.001$; Fig. 2c and d; Table 2), with annual $R_{\mathrm{s}}$ increased by $33.1 \%$ and $19.2-22.8 \%$, respectively (Table 1 ). The low $\mathrm{N}$ deposition effect on $R_{\mathrm{S}}$ was much higher than that of high $\mathrm{N}$ deposition (Fig. $2 \mathrm{c}$ and d). However, $R_{\mathrm{S}}$ was reduced mostly by warming, although not significant ( $P=0.084$; Table 2 ). The high temperatures and low humidity at times of peak sunshine during the diurnal variation significantly inhibited the emission rate (Figs. 3a and b, S2), but it was also significantly increased by warming following extreme rainfall events that increased soil moisture (Fig. 3c and d). The diurnal trend in $R_{\mathrm{S}}$ was consistent with that of soil temperature at $5 \mathrm{~cm}$ depth (Fig. 3). In addition, the interactive responses of $R_{\mathrm{S}}$ to increasing precipitation, warming and $\mathrm{N}$ deposition were much lower than that from any single-factor (Table 1), and with the interaction of $60 \mathrm{~kg} \mathrm{ha}^{-1} \mathrm{~N}$ and extra precipitation decreasing $R_{\mathrm{S}}$ by $4.25 \%$ (Table 1 ). Overall, annual $R_{\mathrm{S}}$
Table 2. Tests of significance of year $(\mathrm{Y})$, warming $(\mathrm{T})$, precipitation $(\mathrm{W})$ and nitrogen addition $(\mathrm{N})$ on soil respiration $\left(R_{\mathrm{S}}\right)$ using multivariate ANOVA ( $F$ and $P$ values). The cumulative effect of precipitation, $\mathrm{N}$ deposition and warming on $R_{\mathrm{S}}$ in 2015 and 2016 ( $F$ and $P$ values) as assessed by repeated measures ANOVA. Superscripts a, $\mathrm{b}$ and $\mathrm{c}$ indicate significant effects at $P<0.05,0.01$ and 0.001 , respectively.

\begin{tabular}{lrrr}
\hline Three-way & $n$ & $F$ & $P$ \\
ANOVA & & & \\
\hline Y & 2 & 26.171 & $<0.001^{\mathrm{c}}$ \\
$\mathrm{N}$ & 424 & 7.709 & $<0.001^{\mathrm{c}}$ \\
$\mathrm{W}$ & 565 & 17.124 & $<0.001^{\mathrm{c}}$ \\
$\mathrm{W} \times \mathrm{N}$ & 424 & 9.392 & $<0.001^{\mathrm{c}}$ \\
$\mathrm{W} \times \mathrm{Y}$ & 424 & 6.899 & $<0.001^{\mathrm{c}}$ \\
$\mathrm{N} \times \mathrm{Y}$ & 424 & 5.561 & $0.004^{\mathrm{b}}$ \\
$\mathrm{Y} \times \mathrm{W} \times \mathrm{N}$ & 424 & 5.963 & $0.003^{\mathrm{b}}$ \\
$\mathrm{T}$ & 424 & 2.320 & 0.084 \\
$\mathrm{~T} \times \mathrm{Y}$ & 424 & 0.536 & 0.464 \\
\hline $\mathrm{Repeated} \mathrm{measures}$ & & & \\
$\mathrm{ANOVA}$ & & & \\
\hline $\mathrm{Y}$ & & & \\
$\mathrm{N}$ & 2 & 30.487 & $<0.000^{\mathrm{c}}$ \\
$\mathrm{W}$ & 383 & 12.887 & $<0.000^{\mathrm{c}}$ \\
$\mathrm{T}$ & 281 & 2.934 & 0.087 \\
$\mathrm{~W} \times \mathrm{N}$ & 142 & 0.965 & 0.326 \\
$\mathrm{~T} \times \mathrm{W} \times \mathrm{N}$ & 281 & 12.755 & $<0.000^{\mathrm{c}}$ \\
\hline
\end{tabular}

rates were significantly impacted by precipitation, $\mathrm{N}$ deposition, and their interaction (Table 2), but no significant net change was caused by warming (Table 2 ), although $R_{\mathrm{S}}$ rates were decreased by $9.99 \%$ (Table 1).

\subsection{Temporal variation and its control}

The results of repeated measures ANOVA showed that significant cumulative effects on $R_{\mathrm{s}}$ were found to be due to $\mathrm{N}$ deposition and interaction between $\mathrm{N}$ deposition and precipitation or warming rather than increasing precipitation and warming alone (Table 2). A large between-year variation in $R_{\mathrm{S}}$ was observed with a coefficient of variation $(\mathrm{CV})$ up to $41.4 \%$ (a much higher $R_{\mathrm{S}}$ rate was observed in 2016 than 2015 ), but variation was reduced by increasing precipitation, $\mathrm{N}$ deposition and warming and their interaction, except with an increase in $\mathrm{N}$ deposition of $30 \mathrm{~kg} \mathrm{ha}^{-1}$ (Table 1). The results of regression analysis showed that $R_{\mathrm{S}}$ was significantly increased by increases in $\mathrm{pH}$ and DOC (Fig. 4e and $\mathrm{f}$ ), but no significant relationships were found with $\mathrm{MBC}, \mathrm{MBN}$ or $\mathrm{NO}_{3}^{-}-\mathrm{N}$ content (Fig. $4 \mathrm{a}, \mathrm{b}$ and $\mathrm{c}$ ). In addition, different response characteristics of $R_{\mathrm{S}}$ in the impacts of increased soil moisture, soil temperature and $\mathrm{NH}_{4}^{+}-\mathrm{N}$ content were found. Soil moisture was the most important controlling factor when it was $<4.2 \%$ and soil temperature was $>26.5^{\circ} \mathrm{C}$ (Figs. $4 \mathrm{~g}$, $\mathrm{h}$ and S2). Secondly, soil temperature was the most impor- 


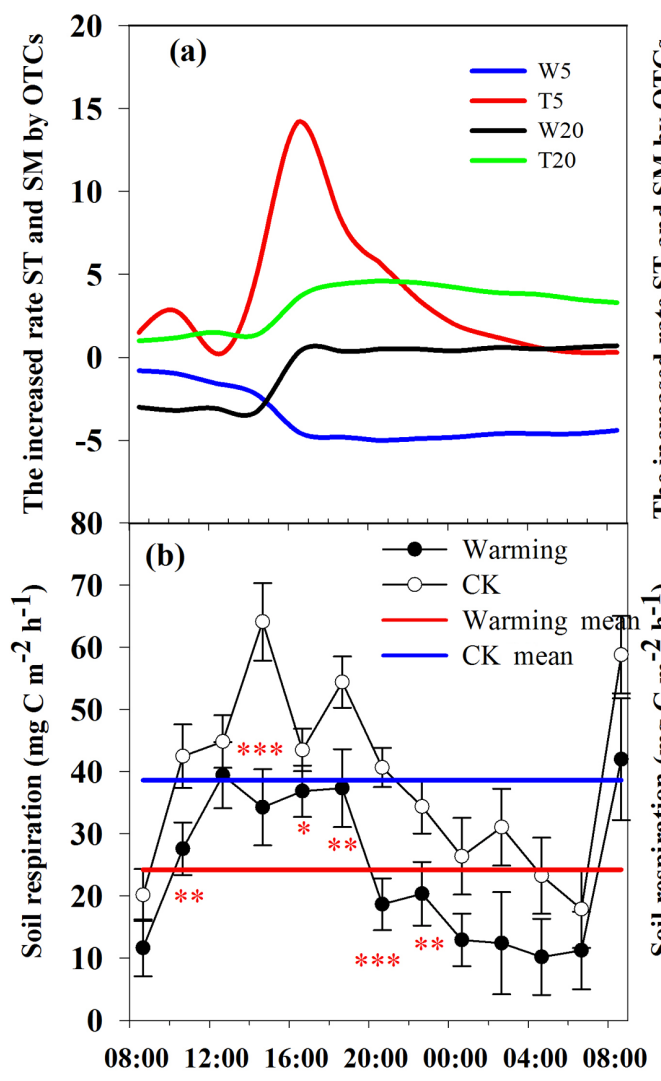

Diurnal variation in extreme drought

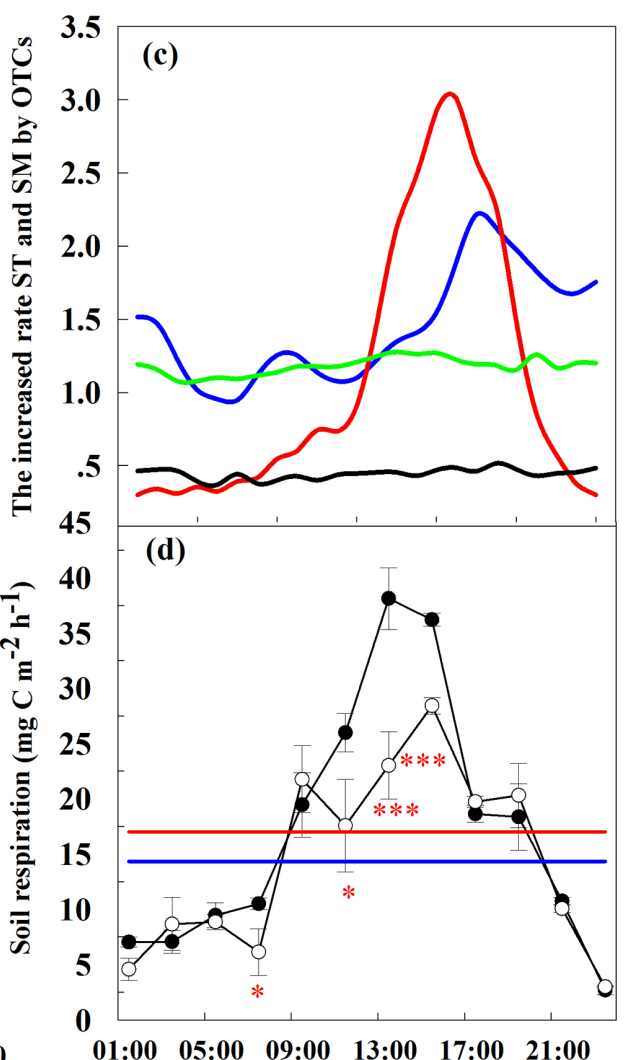

Diurnal variation after extreme rainfall

Figure 3. Post-extreme-rainfall diurnal variation in $R_{\mathrm{S}}$ (mean $\pm \mathrm{SE}, n=4$, d) with variation in soil temperature and soil moisture (c), and extreme-drought variation in $R_{\mathrm{S}}$ (mean $\pm \mathrm{SE}, n=4, \mathbf{b}$ ) with variation in soil temperature (T5, T20, a) and soil moisture at $5 \mathrm{~cm}$ (W5) or $20 \mathrm{~cm}$ (W20) depth caused by warming in OTCs. Positive values indicate an increase due to warming, and negative values indicate decline. A red straight line indicates the average value of $R_{\mathrm{S}}$ inside the OTCs in (b) and (d), and a blue straight line represents the average value of $R_{\mathrm{S}}$ out of OTCs in (b) and (d). Red $* * *$ and $* * *$ symbols indicate significant effects at $P<0.05, P<0.01$ and $P<0.001$, respectively.

tant limiting factor when soil moisture was $>15.9 \%$ and soil temperature $<2.7^{\circ} \mathrm{C}$ (Figs. $4 \mathrm{~g}$, h and S2). Thirdly, there was no significant impact on $R_{\mathrm{S}}$ when soil $\mathrm{NH}_{4}^{+}$-N content was $<6.3 \mathrm{mg} \mathrm{N} \mathrm{kg}^{-1}$. A significant increase in $R_{\mathrm{S}}$ occurred when soil $\mathrm{NH}_{4}^{+}-\mathrm{N}$ content was between 6.3 and $12.6 \mathrm{mg} \mathrm{N} \mathrm{kg}^{-1}$, but $R_{\mathrm{S}}$ was inhibited when soil $\mathrm{NH}_{4}^{+}-\mathrm{N}$ content was between 12.6 and $31.6 \mathrm{mg} \mathrm{N} \mathrm{kg}^{-1}$ (Fig. 4d).

\section{Discussion}

\subsection{Single-factor impacts of precipitation, $\mathrm{N}$ deposition and warming on $R_{\mathrm{S}}$}

Annual $R_{\mathrm{S}}$ was $1090 \mathrm{~kg} \mathrm{Cha}^{-1}$ in this temperate desert, with the non-growing season accounting for $20.7 \%$ of the annual flux (Table 1). This is consistent with previous studies here (Zhou et al., 2014; Huang et al., 2015a) because SOC content was very low (Fig. 1c), and vegetation was very sparse in this desert (R. Liu et al., 2016). Increasing precipitation significantly increased $R_{\mathrm{S}}$ (Fig. 2c). It is also consis- tent with the results of a meta-analysis and previous studies here (Huang et al., 2015a ; L. L. Liu et al., 2016). This is because the growth of desert plants and microbial activity are significantly activated by increasing precipitation (Huang et al., 2015a), and microbial biomass, mass-specific respiration, microbial biomass carbon (MBC) and nitrogen (MBN), and microbial PLFAs (phospholipid fatty acids) were consistently significantly enhanced by increased precipitation (Zhang et al., 2013; Huang et al., 2015a). However, $R_{\mathrm{S}}$ in our study was much higher in moderate soil moisture conditions than with too little or too much soil moisture (Fig. $4 \mathrm{~g}$ ). This suggests that $R_{\mathrm{S}}$ is mainly $\mathrm{R}_{H}$ rather than $R_{\mathrm{A}}$ in this desert, namely from soil microorganism, because (1) too little or too much soil moisture could significantly inhibit microbial activity due to variation of soil temperature and soil properties (Ma et al., 2013), while moderate soil moisture could significantly enhance microbial activity (Skopp et al., 1990) and (2) the biomass of fine roots was not significantly enhanced at our sites by increased precipitation (Cui et al., 2017). This is consistent with results from a desert steppe in 

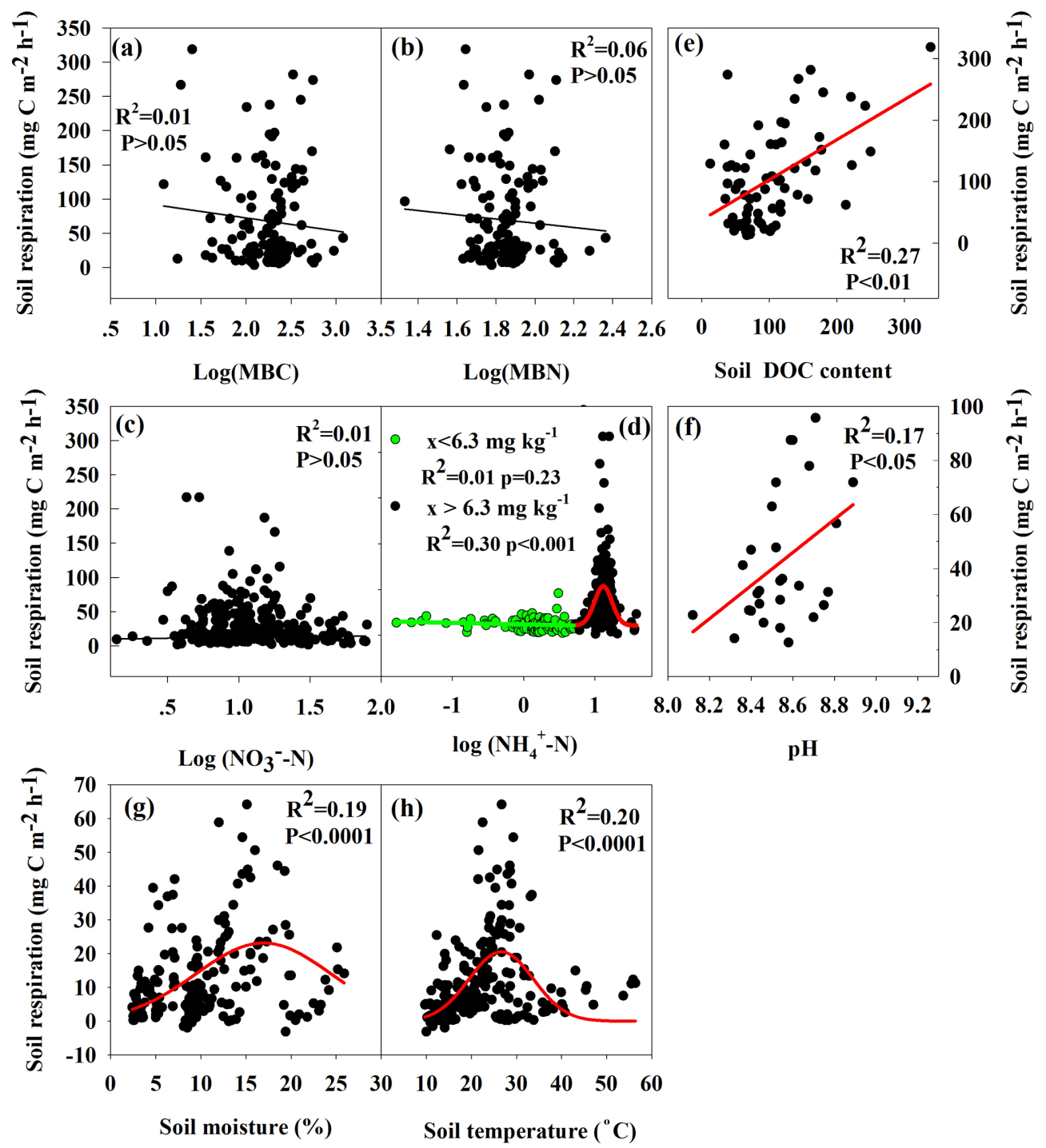

Figure 4. The relationship of soil respiration with microbial biomass carbon $(\mathrm{MBC}, \mathbf{a})$; microbial biomass carbon $\left(\mathrm{MBN}\right.$, b); soil $\mathrm{NO}_{3}-\mathrm{N}$ (c); $\mathrm{NH}_{4}^{+}$-N content $(x, \mathbf{d})$; soil dissolved organic carbon (DOC, e); $\mathrm{pH}(\mathbf{f})$; soil moisture (g) and soil temperature (h).

northern China where the contribution of $R_{\mathrm{H}}(78.1 \%)$ was significantly higher than that of $R_{\mathrm{A}}(21.9 \%)$ under increasing precipitation (T. Liu et al., 2016).

$\mathrm{N}$ deposition also significantly increased $R_{\mathrm{s}}$, especially in low $\mathrm{N}$ deposition (Fig. 2d). This is consistent with results from an alpine meadow and in the Loess Plateau (Fang et al., 2017; Zong et al., 2017), and with a meta-analysis showing that $\mathrm{N}$ deposition increased $R_{\mathrm{S}}$ by $8.8 \%$ (L. Y. Zhou et al., 2016). This is because $\mathrm{N}$ deposition, on the one hand, could increase fine root biomass, although this was not significant in our study (Cui et al., 2017), and on the other hand, increases microbial activity and abundance by low $\mathrm{N}$ deposition (Huang et al., 2015b). However, this was inconsistent with a young Cunninghamia lanceolata forest (Wang et al., 2017), and beneath shrubs of $H$. ammodendron, soil high $\mathrm{N}$ content had the opposite effect as in our study site (Chen et al., 2013; Huang et al., 2015b). Additionally, the results of nonlinear regression analysis showed that higher $R_{\mathrm{s}}$ rates occurred at moderate soil $\mathrm{NH}_{4}^{+}-\mathrm{N}$ contents (between 6.3 and $\left.12.6 \mathrm{mg} \mathrm{N} \mathrm{kg}^{-1}\right)$, while lower $R_{\mathrm{s}}$ occurred in much lower $\left(<6.3 \mathrm{mg} \mathrm{N} \mathrm{kg}^{-1}\right)$ or much higher $\left(>12.6 \mathrm{mg} \mathrm{N} \mathrm{kg}^{-1}\right)$ soil $\mathrm{NH}_{4}^{+}-\mathrm{N}$ contents (Fig. 4d); however, this effect of $\mathrm{N}$ deposition on $R_{\mathrm{S}}$ is not consistent with other ecosystems (Burton et al., 2004; Chen et al., 2013; Liu et al., 2015; Chen et al., 2017b). This is because the desert soil is extremely limited compared to other ecosystem (Adams, 2003), so low $\mathrm{N}$ deposition enhanced plant growth and microbial activity, but high $\mathrm{N}$ inhibited microbial activity and community composition, and reduced $R_{\mathrm{S}}$ (Zhou et al., 2014; Huang et al., 2015b). Overall, soil $\mathrm{NH}_{4}^{+}-\mathrm{N}$ content was an important controlling factor for $R_{\mathrm{S}}$ because microbial activity, abundance and species diversity were regulated by soil $\mathrm{NH}_{4}^{+}-\mathrm{N}$ content 
in this desert, and $R_{\mathrm{S}}$ was very sensitive to variation of $\mathrm{N}$ deposition.

Warming decreased $R_{\mathrm{S}}$ (Fig. 2f), although not significantly $(P=0.084$; Table 2$)$, which was consistent with results from a semi-arid alfalfa pasture of the Loess Plateau (Fang et al., 2017). In addition, significant decreases in $R_{\mathrm{S}}$ were observed on extreme drought or hot sunny days when soil moisture was reduced, and sharply reduced $R_{\mathrm{S}}$ occurred when soil temperature reached $37^{\circ} \mathrm{C}$ (Figs. 3a, b and S1). This is because (i) microbial activity is significantly inhibited by extreme temperatures and low soil moisture may reduce population size by $50-80 \%$ (Sheik et al., 2011) and (ii) fine root growth is inhibited in high temperature and low soil moisture. Others have noted this phenomenon as occurring at about 16:00 each day (Ma et al., 2013), but in our study the effect was advanced to $14: 00$ by warming, which may reduce carbon emission from soil to atmosphere. However, this is not consistent with results from a tundra ecosystem, subtropical forest or alpine regions where $R_{\mathrm{S}}$ was significantly increased by warming due to the limitation of soil temperature in these ecosystems, and not to significant change in soil moisture (Noh et al., 2016; Wu et al., 2016; Y. M. Zhou et al., 2016). In addition, a significant increase in $R_{\mathrm{S}}$ was found following enhanced precipitation with warming (Fig. $3 \mathrm{c}$ and d), which indicates that soil moisture was the most important controlling factor for $R_{\mathrm{S}}$ under a warming climate. This is consistent with other studies (Chen et al., 2017a; Zhao et al., 2017). However, statistical analysis showed that overall no significant impact on $R_{\mathrm{S}}$ was found during the experimental period due to warming (it was reduced by $9.99 \%$ ). This is because our gas samples were taken at 10:00-12:00 each day, when average soil temperatures were increased by about one degree. Thus mean annual $R_{\mathrm{S}}$ was not sensitive to temperature changes this small in contrast to the very significant effects of short-term diurnal changes in soil temperature observed between 12:00 and 17:00 (Fig. 3a and c). However, gas samples during 10:00-12:00 in this study was able to catch the mean warming effects on $R_{\mathrm{S}}$, except in some extreme precipitation and drought events in summer (Fig. S1), which require further systematic evaluation. Those results indicated that $R_{\mathrm{S}}$ depends mainly on variations of soil moisture and temperature in the context of warming, and climate change is likely to have a very significant effect on temperate deserts.

\subsection{The interactive effects of precipitation, $N$ deposition and warming on $\boldsymbol{R}_{\mathrm{s}}$}

Interactive responses of $R_{\mathrm{S}}$ were much lower than those of any single-factor, but still increased $R_{\mathrm{S}}$ overall, except with the interaction between precipitation and high $\mathrm{N}$ deposition (Table 1). This is consistent with results in dry ecosystems (Morillas et al., 2015; Martins et al., 2016), but not with the results of a meta-analysis of precipitation and $\mathrm{N}$ deposition interactive experiments which showed greater posi- tive effects on $R_{\mathrm{S}}$ (L. Y. Zhou et al., 2016). This can be explained in our study due to soil MBC or MBN being much lower in interactive treatments than those of single-factor (Fig. 1d), showing that the number of microorganisms was much smaller in interactive treatments than that of singlefactor due to the much stronger $\mathrm{N}$ effect. As we found that $R_{\mathrm{S}}$ was reduced with increasing $\mathrm{N}$ deposition and precipitation by as much as $4.25 \%$ in W1N2 plots (Table 1), this showed that the inhibiting effect of soil $\mathrm{NH}_{4}^{+}-\mathrm{N}$ content was much stronger when there was sufficient soil moisture (Fig. 2e). This is consistent with the results in a Populus euphratica community in a desert ecosystem (He et al., 2015). This was because (i) microbial activity was inhibited by high or low soil moisture and high soil $\mathrm{NH}_{4}^{+}-\mathrm{N}$ or $\mathrm{NO}_{3}^{-}-\mathrm{N}$ content (Burton et al., 2004) and (ii) high $\mathrm{N}$ content to reduce extracellular enzyme activity and the fungal population (Maris et al., 2015). In addition, the interactive effect of the three factors on $R_{\mathrm{S}}$ in this desert was much lower than interaction of two factors of precipitation and $\mathrm{N}$ deposition (Table 1), and is consistent with the results of modeled interactive effects, which showed that three-factor interactions were rare while two-factor interactions were more common (Luo et al., 2008). Fortunately, the interactive effect of three factors or two factors (precipitation, $\mathrm{N}$ deposition and warming) in this desert could largely reduce between-year variation on $R_{\mathrm{S}}(\mathrm{Ta}-$ ble 2), which may because (i) the limits of soil moisture, soil temperature and soil $\mathrm{N}$ content were lifted for key biological processes by increasing precipitation, $\mathrm{N}$ deposition and warming (Huang et al., 2015a; R. Liu et al., 2016) and (ii) various factors counteracting each other (L. Y. Zhou et al., 2016). However, the effects of the variation on $R_{\mathrm{S}}$ in the growing season on $R_{\mathrm{s}}$ can be increased by warming, elevated precipitation and $\mathrm{N}$ deposition because of their dominant effects on plant growth and microbial activity (Huang et al., $2015 b)$, but it was the exact opposite in the non-growing season due to the reduced temperature limitation (Zeng et al., 2016). Those results showed that $R_{\mathrm{s}}$ would be reduced under interactive effect of increasing rainfall, temperature and $\mathrm{N}$ deposition in the future, and positive carbon-climate feedback took place.

\subsection{Temporal effects of the variation in treatments on $\boldsymbol{R}_{\mathrm{S}}$ and controlling factors}

Significant cumulative effects on $R_{\mathrm{S}}$ were found by elevated $\mathrm{N}$ deposition rather than increasing precipitation and warming alone (Table 2). A previous study here showed that $R_{\mathrm{S}}$ decreased due to $\mathrm{N}$ addition over the experiment's duration (Zhou et al., 2014), which was inconsistent with our results (Fig. 2d) because in our study, we used relatively lower rates of $\mathrm{N}$ addition than that Zhou et al. (2014), and the composition of microbial community and soil properties were altered gradually by long-term and high $\mathrm{N}$ deposition (Fig. 1c and d; Huang et al., 2015b; Zong et al., 2017). In addition, significant cumulative effects in the interaction between 


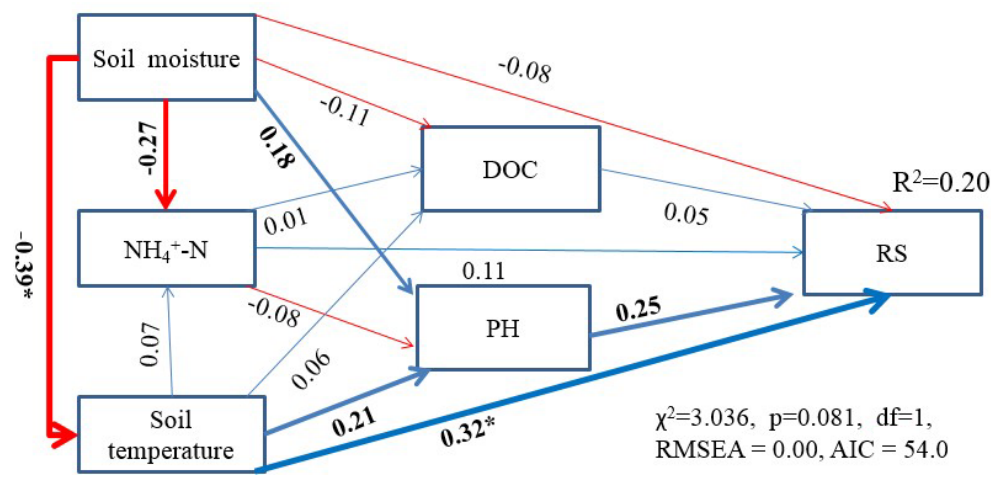

Figure 5. Structure equation model (SEM) testing the multivariate (soil moisture, soil temperature, soil $\mathrm{NH}_{4}^{+}-\mathrm{N}$ content, $\mathrm{DOC}$ and $\mathrm{pH}$ ) effects on $R_{\mathrm{S}}(n=34)$. Arrows show the effects of different key controls on $R_{\mathrm{S}}$ analyzed. The blue arrows indicated positive effects, and red arrows showed negative effects. The width of the arrows indicate the strength of the relationship. The numbers are standardized path coefficients, which can show the importance of the variables in the model. Goodness-of-fit statistics for the model are shown below the model. Asterisks indicate significant effect at $P<0.05$.

$\mathrm{N}$ deposition and precipitation or warming on $R_{\mathrm{S}}$ were also found (Table 2), and $R_{\mathrm{S}}$ decreased by $4.25 \%$ by interaction between increasing precipitation and high $\mathrm{N}$ deposition (Table 1), which indicated that the response of $R_{\mathrm{S}}$ to $\mathrm{N}$ deposition is largely dependent on soil moisture in desert soil. This may be attributed to the antagonistic interaction between elevated $\mathrm{N}$ deposition and precipitation on $\mathrm{R}_{h}$ (L. Y. Zhou et al., 2016). Those results indicated that $\mathrm{N}$ deposition produced strong cumulative effects on $R_{\mathrm{S}}$ in this desert, and was enhanced largely with increasing soil moisture, which would reduce carbon emission from soil to atmosphere.

Regression analysis shows that $R_{\mathrm{S}}$ exhibited a unimodal change pattern with variations of soil $\mathrm{NH}_{4}^{+}-\mathrm{N}$ (Fig. 4d), moisture (Fig. $4 \mathrm{~g}$ ), and temperature (Fig. $4 \mathrm{~h}$ ), and $R_{\mathrm{S}}$ was significantly positively correlated to soil dissolved organic carbon (DOC) and $\mathrm{pH}$ (Fig. 4e and f). However, structural equation modeling indicated that soil temperature was a more important controlling factor than soil $\mathrm{NH}_{4}^{+}-\mathrm{N}$ and soil moisture (Fig. 5). This is consistent with most research results (Wu et al., 2016; Y. M. Zhou et al., 2016; Chen et al., 2017a). In addition, a large interannual variation was observed $(\mathrm{CV}=41.4 \%)$ during our experiment (Table 1), while the variation of annual precipitation and air temperature were only 4.41 and $7.78 \%$, respectively (Table 1), but close to the $\mathrm{CV}$ of spring root biomass of ephemeral plants $(47.14 \%)$, with 24 times greater aboveground biomass of spring ephemeral plants in 2016 than in 2015 (Cui et al., 2017), which indicated that the increase of $R_{\mathrm{S}}$ in 2016 was mainly from the root respiration of ephemeral plants. This is consistent with previous studies showing that ephemeral plants mediated the interannual variations of carbon fluxes in this desert (Huang et al., 2015c; R. Liu et al., 2016). It is different from other ecosystems where interannual variations of $R_{\mathrm{S}}$ were mainly dependent on variations in annual precipitation and air temperature (Gerard et al., 1999; Asensio et al., 2007; Chen et al., 2012). Overall, our results indicate that annual variation in $R_{\mathrm{S}}$ in this temperate desert is mainly controlled by soil temperature, but between-year variation in $R_{\mathrm{S}}$ is mainly controlled by ephemeral plants.

\section{Conclusions}

Climate change and elevated $\mathrm{N}$ deposition play important roles in controlling $R_{\mathrm{S}}$ in temperate deserts. We found that increasing precipitation and $\mathrm{N}$ deposition significantly increased $R_{\mathrm{S}}$ in the Gurbantunggut Desert, but warming reduced $R_{\mathrm{S}}$, mostly because of the variation of soil moisture. In addition, we found that the interactive responses of $R_{\mathrm{S}}$ were much lower for the combination of precipitation, $\mathrm{N}$ deposition and warming than for any single factor. Additionally, $R_{\mathrm{S}}$ is mainly mediated by soil moisture, soil temperature and soil $\mathrm{NH}_{4}^{+}-\mathrm{N}$ content, but soil temperature is the most important, with between-year variation in $R_{\mathrm{S}}$ mainly controlled by ephemeral plants. These results showed that $R_{\mathrm{S}}$ is very sensitive to increasing precipitation, $\mathrm{N}$ deposition and warming, and their interactive effects could reduce soil carbon emissions and thus the impacts of climate change.

Data availability. All data used to generate the figures are available upon request to the corresponding author.

Supplement. The supplement related to this article is available online at: https://doi.org/10.5194/bg-15-2007-2018-supplement.

Competing interests. The authors declare that they have no conflict of interest. 
Special issue statement. This article is part of the special issue "The 10th International Carbon Dioxide Conference (ICDC10) and the 19th WMO/IAEA Meeting on Carbon Dioxide, other Greenhouse Gases and Related Measurement Techniques (GGMT-2017) (AMT/ACP/BG/CP/ESD inter-journal SI)". It is a result of the 19th WMO/IAEA Meeting on Carbon Dioxide, Other Greenhouse Gases, and Related Measurement Techniques (GGMT-2017), Empa Dübendorf, Switzerland, 27-31 August 2017.

Acknowledgements. This work was financially supported by the Chinese National Basic Research Program (2014CB954202), the National Natural Science Foundation of China (41603084, $41703131,41425007)$, the special training program for science and technology talents of ethnic minorities in Xinjiang (2016D0201) and the Ten-Thousand Talent Program (Xuejun Liu). Keith Goulding was supported by the Sino-UK cooperative project on nitrogen (CINAg).

Edited by: Christoph Heinze

Reviewed by: two anonymous referees

\section{References}

Adams, M. B.: Ecological issues related to $\mathrm{N}$ deposition to natural ecosystems: research needs, Environ. Int., 29, 189-199, https://doi.org/10.1016/S0160-4120(02)00179-4, 2003.

Asensio, D., Penuelas, J., Llusia, J., Ogaya, R., and Filella, L: Interannual and interseasonal Soil $\mathrm{CO}_{2}$ efflux and VOC exchange rates in a Mediterranean holm oak forest in response to experimental drought, Soil Biol. Biochem., 39, 2471-2484, https://doi.org/10.1016/j.soilbio.2007.04.019, 2007

Batjes, N. H.: Total carbon and nitrogen in the soils of the world, Eur. J. Soil Sci., 47, 151-163, https://doi.org/10.1111/j.13652389.1996.tb01386.x, 1996.

Brookes, P. C.: Microbial biomass and activity measurements in soil, J. Sci. Food Agric., 36, 269-270, 1985.

Burton, A. J., Pregitzer, K. S., Crawford, J. N., Zogg, G. P., and Zak, D. R.: Simulated chronic $\mathrm{NO}_{3}^{-}$deposition reduces soil respiration in northern hardwood forests, Glob. Change Biol., 10, 10801091, https://doi.org/10.1111/j.1365-2486.2004.00737.x, 2004.

Chen, J., Zhou, X. H., Hruska, T., Cao, J. J., Zhang, B. C., Liu, C., Liu, M., Shelton, S., Guo, L., Wei, Y. L., Wang, J. F., Xiao, S., and Wang, P.: Asymmetric diurnal and monthly responses of ecosystem carbon fluxes to experimental warming, Clean-Soil Air Water, 45, 1600557, https://doi.org/10.1002/clen.201600557, 2017a.

Chen, S. T., Huang, Y., Zou, J. W., Shi, Y. S., Lu, Y. Y., Zhang, W., and $\mathrm{Hu}, \mathrm{Z}$. H.: Interannual variability in soil respiration from terrestrial ecosystems in China and its response to climate change, Sci. China Earth. Sci., 55, 2091-2098, 2012.

Chen, W. W., Zheng, X. H., Chen, Q., Wolf', B., ButterbachBahl, K., Bruggemann, N., and Lin, S.: Effects of increasing precipitation and nitrogen deposition on $\mathrm{CH}_{4}$ and $\mathrm{N}_{2} \mathrm{O}$ fluxes and ecosystem respiration in a degraded steppe in Inner Mongolia, China, Geoderma, 192, 335-340. https://doi.org/10.1016/j.geoderma.2012.08.018, 2013.
Chen, Z. J., Setala, H., Geng, S. C., Han, S. J., Wang, S. Q., Dai, G. H., and Zhang, J. H.: Nitrogen addition impacts on the emissions of greenhouse gases depending on the forest type: a case study in Changbai Mountain, Northeast China, J. Soil Sediment, 17, 23-34, https://doi.org/10.1007/s11368-016-1481-7, $2017 \mathrm{~b}$.

Cui, X., Yue, P., Gong, Y., Li, K., Tan, D., Goulding, K., and Liu, X.: Impacts of water and nitrogen addition on nitrogen recovery in Haloxylon ammodendron dominated desert ecosystems, Sci. Total Environ., 601, 1280-1288, https://doi.org/10.1016/j.scitotenv.2017.05.202, 2017.

Eswaran, H., Van Den Berg, E., and Reich, P.: Organic carbon in soils of the world, Soil Sci. Soc. Am. J., 57, 192-194, https://doi.org/10.2136/sssaj1993.03615995005700010034x, 1993.

Fang, C., Ye, J. S., Gong, Y. H., Pei, J. Y., Yuan, Z. Q., Xie, C., Zhu, Y. S., and Yu, Y. Y.: Seasonal responses of soil respiration to warming and nitrogen addition in a semi-arid alfalfa-pasture of the Loess Plateau, China, Sci. Total Environ., 590, 729-738, https://doi.org/10.1016/j.scitotenv.2017.03.034, 2017.

Feng, J. G., Wang, J. S., Ding, L. B., Yao, P. P., Qiao, M. P., and Yao, S. C.: Meta-analyses of the effects of major global change drivers on soil respiration across China, Atmos. Environ., 150, 181-186, https://doi.org/10.1016/j.atmosenv.2016.11.060, 2017.

Galloway, J. N., Townsend, A. R., Erisman, J. W., Bekunda, M., Cai, Z., Freney, J. R., and Sutton, M. A. . Transformation of the nitrogen cycle: recent trends, questions, and potential solutions, Science, 320, 889-892. https://doi.org/10.1126/science.1136674, 2008.

Gerard, J. C., Nemry, B., Francois, L. M., and Warnant, P.: The interannual change of atmospheric $\mathrm{CO}_{2}$ : contribution of subtropical ecosystems?, Geophys. Res. Lett., 26, 243-246, https://doi.org/10.1029/1998GL900269, 1999.

Gougoulias, C., Clark, J. M., and Shaw, L. J.: The role of soil microbes in the global carbon cycle: tracking the below - microbial processing of plant - carbon for manipulating carbon dynamics in agricultural systems, J. Sci. Food Agr., 94, 2362-2371, https://doi.org/10.1002/jsfa.6577, 2014.

Hanson, P. J., Edwards, N. T., Garten, C. T., and Andrews, J. A.: Separating root and soil microbial contributions to soil respiration: A review of methods and observations, Biogeochemistry, 48, 115-146, https://doi.org/10.1023/A:1006244819642, 2000.

He, X., Lv, G., Qin, L., Chang, S., Yang, M., Yang, J., and Yang, X.: Effects of simulated nitrogen deposition on soil respiration in a Populus euphratica community in the Ebinur Lake area, a desert ecosystem of northwestern China, PloS one, 10, 1-16, https://doi.org/10.1371/journal.pone.0137827, 2015.

Heimann, M. and Reichstein, M.: Terrestrial ecosystem carbon dynamics and climate feedbacks, Nature, 451, 289-292, https://doi.org/10.1038/nature06591, 2008.

Huang, G., Li, Y., and Su, Y. G.: Effects of increasing precipitation on soil microbial community composition and soil respiration in a temperate desert, Northwestern China, Soil Biol. Biochem., 83, 52-56, https://doi.org/10.1016/j.soilbio.2015.01.007, 2015a.

Huang, G., Cao, Y. F., Wang, B., and Li, Y.; Effects of nitrogen addition on soil microbes and their implications for soil C emission in the Gurbantunggut Desert, Center of the Eurasian Continent, Sci. Total Environ., 515, 215-224, https://doi.org/10.1016/j.scitotenv.2015.01.054, 2015 b. 
Huang, G., Li, Y., and Padilla, F. M.: Ephemeral plants mediate responses of ecosystem carbon exchange to increased precipitation in a temperate desert, Agr. Forest Meteorol., 201, 141-152, https://doi.org/10.1016/j.agrformet.2014.11.011, 2015c.

IPCC: Climate Change 2013: the Physical Science Basis. Contribution of Working Group I to the Fifth Assessment Report of the Intergovernmental Panel on Climate Change, Cambridge University Press, Cambridge, UK and New York, NY, USA, 1535 pp., 2013.

Jiang, X., Cao, L., and Zhang, R.: Changes of labile and recalcitrant carbon pools under nitrogen addition in a city lawn soil, J. Soils Sediments, 14, 515-524, https://doi.org/10.1007/s11368013-0822-z, 2014.

Jones, D. L. and Willett, V. B.: Experimental evaluation of methods to quantify dissolved organic nitrogen (DON) and dissolved organic carbon (DOC) in soil, Soil Biology and Biochemistry, 38, 991-999, https://doi.org/10.1016/j.soilbio.2005.08.012, 2006.

Lafleur, P. M. and Humphreys, E. R.,: Spring warming and carbon dioxide exchange over low Arctic tundra in central Canada, Glob. Change Biol., 14, 740-756, https://doi.org/10.1111/j.13652486.2007.01529.x, 2008.

Li, G., Kim, S., Han, S. H., Chang, H., and Son, Y.: Effect of soil moisture on the response of soil respiration to open-field experimental warming and precipitation manipulation, Forests, 8, 1-10, 2017.

Liu, C., Wang, K., and Zheng, X.: Responses of $\mathrm{N}_{2} \mathrm{O}$ and $\mathrm{CH}_{4}$ fluxes to fertilizer nitrogen addition rates in an irrigated wheatmaize cropping system in northern China, Biogeosciences, 9, 839-850, https://doi.org/10.5194/bg-9-839-2012, 2012.

Liu, L. L., Wang, X., Lajeunesse, M. J., Miao, G. F., Piao, S. L., Wan, S. Q., Wu, Y. X., Wang, Z. H., Yang, S., Li, P., and Deng, M. F.: A cross-biome synthesis of soil respiration and its determinants under simulated precipitation changes, Glob. Change Biol., 22, 1394-1405, https://doi.org/10.1111/gcb.13156, 2016.

Liu, L. T., Hu, C. S., Yang, P. P., Ju, Z. Q., Olesen, J. E., and Tang, J. W.: Effects of experimental warming and nitrogen addition on soil respiration and $\mathrm{CH}_{4}$ fluxes from crop rotations of winter wheat-soybean/fallow, Agr. Forest Meteorol., 207, 38-47, https://doi.org/10.1016/j.agrformet.2015.03.013, 2015.

Liu, R., Cieraad, E., Li, Y., and Ma, J.: Precipitation pattern determines the inter-annual variation of herbaceous layer and carbon fluxes in a phreatophyte-dominated desert ecosystem, Ecosystems, 19, 601-614, https://doi.org/10.1007/s10021-015-9954-x, 2016.

Liu, T., Xu, Z. Z., Hou, Y. H., and Zhou, G. S.: Effects of warming and changing precipitation rates on soil respiration over two years in a desert steppe of northern China, Plant Soil., 400, 1527, https://doi.org/10.1007/s11104-015-2705-0, 2016.

Liu, Y., Li, X., Zhang, Q., Guo, Y., Gao, G., and Wang, J.: Simulation of regional temperature and precipitation in the past 50 years and the next 30 years over China, Quatern. Int., 212, 57-63 https://doi.org/10.1016/j.quaint.2009.01.007, 2010.

Luo, C. Y., Wang, S. P., Zhao, L., Xu, S. X., Xu, B. R. B. Y., Zhang, Z. H., Yao, B. Q., and Zhao, X. Q.: Effects of land use and nitrogen fertilizer on ecosystem respiration in alpine meadow on the Tibetan Plateau, J. Soil Sediment., 17, 16261634, https://doi.org/10.1016/j.quaint.2009.01.007, 2017.

Luo, Y., Gerten, D., Le Maire, G., Parton, W. J., Weng, E., Zhou, X., Keough, C., Beier, C., Ciais, P., and Cramer, W.: Modeled inter- active effects of precipitation, temperature, and $\mathrm{CO}_{2}$ on ecosystem carbon and water dynamics in different climatic zones, Glob. Change Biol., 14, 1986-1999, https://doi.org/10.1111/j.13652486.2008.01629.x, 2008.

Ma, J., Wang, Z.-Y., Stevenson, B. A., Zheng, X.-J., and Li, Y.: An inorganic $\mathrm{CO}_{2}$ diffusion and dissolution process explains negative $\mathrm{CO}_{2}$ fluxes in saline/alkaline soils, Sci. Rep-Uk., 3, 2025, https://doi.org/10.1038/srep02025, 2013.

Marion, G. M., Henry, G. H. R., Freckman, D. W., Johnstone, J., Jones, G., Jones, M. H., and Virginia, R. A.: Open-top designs for manipulating field temperature in highlatitude ecosystems, Glob. Change Biol., 1997, 3, 20-32, https://doi.org/10.1111/j.1365-2486.1997.gcb136.x, 2003.

Maris, S. C., Teira-Esmatges, M. R., Arbonés, A., and Rufat, J.: Effect of irrigation, nitrogen application, and a nitrification inhibitor on nitrous oxide, carbon dioxide and methane emissions from an olive (Olea europaea L.) orchard, Sci. Total Environ., 538, 966-978, https://doi.org/10.1016/j.scitotenv.2015.08.040, 2015.

Martins, C. S. C., Macdonald, C. A., Anderson, I. C., and Singh, B. K.: Feedback responses of soil greenhouse gas emissions to climate change are modulated by soil characteristics in dryland ecosystems, Soil Biol. Biochem., 100, 21-32, https://doi.org/10.1016/j.soilbio.2016.05.007, 2016.

Morillas, L., Duran, J., Rodriguez, A., Roales, J., Gallardo, A., Lovett, G. M., and Groffman, P. M.: Nitrogen supply modulates the effect of changes in drying-rewetting frequency on soil $\mathrm{C}$ and $\mathrm{N}$ cycling and greenhouse gas exchange Global Change Biol., 21, 3854-3863, https://doi.org/10.1111/gcb.12956, 2015.

Noh, N. J., Kuribayashi, M., Saitoh, T. M., Nakaji, T., Nakamura, M., Hiura, T., and Muraoka, H.: Responses of soil, heterotrophic, and autotrophic respiration to experimental open-field soil warming in a cool-temperate deciduous forest, Ecosystems, 19, 504520, https://doi.org/10.1007/s10021-015-9948-8, 2016.

Sheik, C. S., Beasley, W. H., Elshahed, M. S., Zhou, X., Luo, Y., and Krumholz, L. R.: Effect of warming and drought on grassland microbial communities, The ISME Journal, 5, 1692-1700, https://doi.org/10.1038/ismej.2011.32, 2011.

Skopp, J., Jawson, M. D., and Doran, J. W.: Steadystate aerobic microbial activity as a functionof soil watercontent, Soil Sci. Soc. Am., 54, 1619-1625, https://doi.org/10.2136/sssaj1990.03615995005400060018x, 1990.

Song,W.:Characteristics of Chemical Composition and Deposition Fluxes of Atmospheric Particles and Reactive Nitrogen in Typical Ecosystems of Xinjiang, China, PhD Thesis, Xinjiang Institute of Ecology and Geography, China, 2015.

Strong, A. L., Johnson, T. P., Chiariello, N. R., and Field, C. B.: Experimental fire increases soil carbon dioxide efflux in a grassland long-term multifactor global change experiment, Global Change Biol., 23, 1975-1987, https://doi.org/10.1111/gcb.13525, 2017.

Wang, Q. K., Zhang, W. D., Sun, T., Chen, L. C., Pang, X. Y., Wang, Y. P., and Xiao, F. M.: N and P fertilization reduced soil autotrophic and heterotrophic respiration in a young Cunninghamia lanceolata forest, Agr. Forest Meteorol., 232, 66-73, https://doi.org/10.1016/j.agrformet.2016.08.007, 2017.

Wu, C. S., Liang, N. S., Sha, L. Q., Xu, X. L., Zhang, Y. P., Lu, H. Z., Song, L., Song, Q. H., and Xie, Y. N.: Heterotrophic respiration does not acclimate to continuous 
warming in a subtropical forest, Sci. Rep-Uk, 6, 21561, https://doi.org/10.1038/srep21561, 2016.

Wu, Z. T., Dijkstra, P., Koch, G. W., Penuelas, J., and Hungate, B. A.: Responses of terrestrial ecosystems to temperature and precipitation change: a meta-analysis of experimental manipulation, Glob. Change Biol., 17, 927-942, https://doi.org/10.1111/j.13652486.2010.02302.x, 2011.

Yang, G., Wang, M., Chen, H., Liu, L. F., Wu, N., Zhu, D., Tian, J. Q., Peng, C. H., Zhu, Q. A., and He, Y. X.: Responses of $\mathrm{CO}_{2}$ emission and pore water DOC concentration to soil warming and water table drawdown in Zoige Peatlands, Atmos. Environ., 152, 323-329, https://doi.org/10.1016/j.atmosenv.2016.12.051, 2017.

Yue, P., Li, K., Gong, Y., Hu, Y., Mohammat, A., Christie, P., and Liu, X.: A five-year study of the impact of nitrogen addition on methane uptake in alpine grassland, Sci. Rep-UK, 6, 32064, https://doi.org/10.1038/srep32064, 2016.

Zeng, X. H., Song, Y. G., Zeng, C. M., Zhang, W. J., and He, S. B.: Partitioning soil respiration in two typical forests in semi-arid regions, North China, Catena, 147, 536-544, https://doi.org/10.1016/j.catena.2016.08.009, 2016.

Zhang, N., Liu, W., Yang, H., Yu, X., Gutknecht, J. L. M., Zhang, Z., Wan, S., and Ma, K.: Soil microbial responses to warming and increased precipitation and their implications for ecosystem C cycling, Oecologia, 173, 1125-1142, https://doi.org/10.1007/s00442-013-2685-9, 2013.

Zhang, W., Liu, C. Y., Zheng, X. H., Fu, Y. F., Hu, X. X., Cao, G. M., and Butterbach-Bahl, K.: The increasing distribution area of zokor mounds weaken greenhouse gas uptakes by alpine meadows in the Qinghai-Tibetan Plateau, Soil Biol. Biochem., 71, 105-112, https://doi.org/10.1016/j.soilbio.2014.01.005, 2014.

Zhang, X. L., Tan, Y. L., Zhang, B. W., Li, A., Daryanto, S., Wang, L. X., and Huang, J. H.: The impacts of precipitation increase and nitrogen addition on soil respiration in a semiarid temperate steppe, Ecosphere, 8, e01655, https://doi.org/10.1002/ecs2.1655, 2017.
Zhao, Z. Z., Dong, S. K., Jiang, X. M., Liu, S. L., Ji, H. Z., Li, Y., Han, Y. H., and Sha, W.: Effects of warming and nitrogen deposition on $\mathrm{CH}_{4}, \mathrm{CO}_{2}$ and $\mathrm{N}_{2} \mathrm{O}$ emissions in alpine grassland ecosystems of the Qinghai-Tibetan Plateau, Sci. Total Environ., 592, 565-572, https://doi.org/10.1016/j.scitotenv.2017.03.082, 2017.

Zhong, Y. Q. W., Yan, W. M., and Shangguan, Z. P.: The effects of nitrogen enrichment on soil $\mathrm{CO}_{2}$ fluxes depending on temperature and soil properties, Global Ecol. Biogeogr., 25, 475-488, https://doi.org/10.1111/geb.12430, 2016.

Zhou, L. Y., Zhou, X. H., Shao, J. J., Nie, Y. Y., He, Y. H., Jiang, L. L., Wu, Z. T., and Bai, S. H.: Interactive effects of global change factors on soil respiration and its components: a meta-analysis, Glob. Change Biol., 22, 3157-3169, https://doi.org/10.1111/gcb.13253, 2016.

Zhou, X. B. and Zhang, Y. M.: Seasonal pattern of soil respiration and gradual changing effects of nitrogen addition in a soil of the Gurbantunggut Desert, northwestern China, Atmos. Environ., 85, 187-194, https://doi.org/10.1016/j.atmosenv.2013.12.024, 2014.

Zhou, Y. M., Hagedorn, F., Zhou, C. L., Jiang, X. J., Wang, X. X., and Li, M. H.: Experimental warming of a mountain tundra increases soil $\mathrm{CO}_{2}$ effluxes and enhances $\mathrm{CH}_{4}$ and $\mathrm{N}_{2} \mathrm{O}$ uptake at Changbai Mountain, China, Sci Rep-UK, 6, 21108, https://doi.org/10.1038/srep21108, 2016.

Zhu, J., Kang, F. F., Chen, J., Cheng, X. Q., and Han, H. R.: Effect of nitrogen addition on soil respiration in a Larch Plantation, Pol. J. Environ. Stud., 26, 1403-1412, https://doi.org/10.15244/pjoes/67687, 2017.

Zong, N., Shi, P. L., Chai, X., Jiang, J., Zhang, X. Z., and Song, M. H.: Responses of ecosystem respiration to nitrogen enrichment and clipping mediated by soil acidification in an alpine meadow, Pedobiologia, 60, 1-10, https://doi.org/10.1016/j.pedobi.2016.11.001, 2017. 